\title{
In Memoriam: John A. Hansen
}

\author{
Paul J. Martin ${ }^{1}$ Effie W. Petersdorf ${ }^{1}$
}

Received: 28 August 2019 / Revised: 8 October 2019 / Accepted: 8 October 2019 / Published online: 10 January 2020

C) Springer Nature Limited 2020

On behalf of our colleagues and readers of this journal, we remember John A. Hansen, who died peacefully at home on July 31, 2 years after a diagnosis of pancreatic cancer. As a medical student at Stanford, Dr Hansen worked in the cardiac transplantation program led by Norm Shumway, thinking that he might pursue a career in cardiac surgery. During studies of immunology with Leslie Brent at St. Mary's Hospital Medical School in London and with Robert Good and Bo DuPont at the University of Minnesota, he came to the realization that the problem of graft rejection could not be overcome unless we understood histocompatibility. After 4 years as a faculty member at Memorial Sloan Kettering and Cornell, he was recruited to the Fred Hutchinson Cancer Research Center, the University of Washington and the Puget Sound Blood Center in 1977 to serve as the Director of the HLA laboratory.

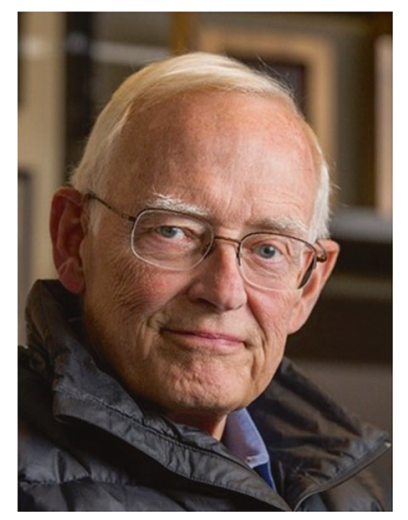

Photo courtesy of Robert Hood.

This article is co-published in the journals Bone Marrow Transplantation and Biology of Blood and Marrow Transplantation. https://doi.org/10.1016/j.bbmt.2019.10.001.

Effie W. Petersdorf

epetersd@fredhutch.org

1 Fred Hutchinson Cancer Research Center, University of Washington, Seattle, WA, USA
Dr Hansen's contributions to the field are well known to readers of this journal. After initial efforts to advance HLA typing through development of monoclonal antibodies, he adopted and advanced the molecular methods that have evolved to current sequencing-based technologies. In the clinical arena, he extended the reach of hematopoietic cell transplantation from HLA-genotypically matched sibling donors to HLA-partially matched relatives and from there to phenotypically matched unrelated donors. At the national and international level, he advanced the field through participation in histocompatibility workshops, and after his success with the first HLA-matched unrelated transplant for treatment of leukemia in 1979, he helped develop the National Marrow Donor Program and similar unrelated registries in Germany and China.

Dr Hansen's contributions in immunogenetics, the clinical application of HLA matching in hematopoietic cell transplantation and the development of the NMDP and other donor registries demonstrate outstanding $\mathrm{A}-\mathrm{Z}$ translational science that propelled the field in its early days. Whereas suitable donors were available for only $30 \%$ of patients who could benefit from hematopoietic cell transplantation in the 1970s, it is now possible to find a donor for virtually all patients who could benefit from this procedure.

Both of us began our scientific careers in John's laboratory at the FHCRC. Neither of us had much prior experience in laboratory work or clinical investigation. As he did for so many others, John generously provided the space, resources, one-on-one attention and guidance that launched our careers, and he helped us develop the skills in writing scientific reports and grant applications that have sustained our own work. As we matured through academic adolescence, he graciously encouraged us to pursue independent work. He taught us that collaboration with others enhances the success of our academic work. As the chair of the international HLA workshop in 2002, John did what he loved most: bringing together diverse scientific communities to achieve a common goal, showing us how the whole is greater than 
the sum of the parts. John personified mentorship at its best and taught us the most important lesson of all: how to be good mentors in our own right. Inspired by his example, we strive to pass the legacy of what we learned from him to the next generation of colleagues who have worked with us.

Work in human immunogenetics and hematopoietic cell transplantation has an inherently cosmopolitan and international nature. John's innate curiosity, gregarious character and personal warmth fit right in with his enjoyment of international travel, meeting new people and teamwork. The work in his laboratory extended far beyond trainees from the FHCRC in welcoming visitors from Asia, Europe, North Africa and South America. Many of these trainees have gone on to leadership positions in transplantation and cancer immunotherapy, joining us in extending his legacy in their own work.

At age 76, John died young. His cancer diagnosis coincided with the successful renewal of an NIH grant application to continue studies of genetic polymorphisms outside the major histocompatibility complex as related to outcomes after hematopoietic cell transplantation. After his cancer diagnosis, he found considerable personal meaning and satisfaction from his continued work on this project and his work with DKMS, the German unrelated donor registry. He lived his last 2 years just as he lived his prior life. The work now rests in the hands of others who have promised to bring this scientific part of his legacy to completion. 